\title{
Colony-forming ability of marrow from patients receiving immunotherapy during chemotherapy- induced remission in acute myeloid leukaemia
}

\author{
M. Y. GORDON 1 , R. L. POWLES ${ }^{2}$, AND I. D. C. DOUGLAS 3 \\ From the Department of Biophysics, Institute of Cancer Research, Sutton, Surrey ${ }^{1}$, and the Division of \\ Medicine ${ }^{2}$, and Department of Haematology ${ }^{3}$, Royal Marsden Hospital, Sutton, Surrey
}

SUMMARY An in vivo culture system, the agar diffusion chamber technique, has been used to measure the population of colony-forming precursor cells in the bone marrow of patients receiving immunos therapy during acute myeloid leukaemia in remission. The results of these assays indicate that (1) the level of committed granulocytic stem cells usually remains below the range found in normal marrow throughout remission, and (2) the maintenance of adequate cell counts in the blood may be due t $\vec{g}$ increased cell production by these early granulocytic precursor cells. The relevance of these findings to the possible protective effect of immunotherapy against cytotoxic chemotherapy is discussed.

The rationale for cancer immunotherapy in man is that the immune system of a host with a small amount of residual tumour will destroy the remaining malignant cells when stimulated with nonspecific agents such as BCG and/or specific agents such as tumour cells (see review by Currie (1972)). Studies in acute myeloblastic leukaemia have shown that immunotherapy of this sort prolongs the survival of patients in remission (Powles, 1973; Powles et al., 1973). However, the mechanism of action of immunotherapy in these studies is uncertain. Although immunotherapy stimulates the immune system of the patients, as shown by humoral (Klouda et al., 1975) and cell-mediated response to the antigens given (Powles et al., 1971), a specific attack by the host against autologous leukaemic cells has not been detected (Powles, 1976).

It is of particular importance that the survival of patients receiving immunotherapy is significantly better after relapse than for those not receiving immunotherapy. This cannot be explained in terms of active specific immunity which is non-existent or ineffective by the time of relapse. It has been suggested, therefore, that a non-specific mechanism acting during remission may still be of influence in subsequent relapse. One possibility is that stimulation of the normal haemopoietic precursor cells creates (or induces) a greater marrow reserve so that patients can better withstand the required reinducReceived for publication 16 March 1976 tion chemotherapy (Powles, 1976).

Several techniques are already available foi studying granulopoiesis. The in vitro growth of bonf marrow colony-forming cells has been used in severaf centres to monitor granulopoiesis in acute myeloig leukaemia. Whereas granulocytic precursor cels in normal bone marrow produce colonies of morg than 50 cells when cultured in agar in vitro (Robinson and Pike, 1970), in acute myeloid leukaemia there are abnormal growth patterns in vitro. Untreated leukaemias may produce large numbers of clusters. (fewer than 50 cells) which may or may not be ac companied by colony formation, or there may be no growth at all (Moore et al., 1974). Almost withoud exception, complete haematological remission is res ported to be associated with a return to norma numbers of colony-forming cells in the marrow (Brown and Carbone, 1971; Moore et al., 1973; Bư et al., 1973).

More recently, an 'in vivo' method for assayingy colony-forming cells has been developed (Gordon al., 1975) whereby human bone marrow cells can be grown in agar in diffusion chambers in mice. The colonies grown by this method from normal huma\& marrow cells appear to be morphologically and cyto logically very similar to those grown in vitros Furthermore, cultures of cells from untreated AMP patients show the same incidence of cluster and colony formation as is seen in vitro (unpublisheg data). 
This communication reports the results from such assays of the colony-forming ability of marrow from acute myeloid leukaemia patients in remission. These patients were all treated with immunotherapy over a range of remission lengths from 0 to 12 months, and an attempt was made to see if any link could be found between the numbers of colony-forming cells, the white blood cell count, and the subsequent clinical response following relapse.

Secondly, as it has been shown that the sensitivity of the colony-forming cells to the S-phase specific agent, cytosine arabinoside, is related to their proliferation rate at the time of marrow biopsy (Gordon and Douglas, 1975), the sensitivity of the colonyforming cells in the remission marrows was compared with that of colony-forming cells in haematologically normal marrow aspirates.

\section{Material and methods}

\section{SOURCE OF HUMAN MARROW}

Seventeen patients with acute myeloid leukaemia, all of whom were initially in remission, were included in this study.

To induce remission they were treated with a 24-hour infusion of cytosine arabinoside $(10 \mathrm{mg} / \mathrm{kg})$ followed by one or two daily injections of an anthracycline $(1.5 \mathrm{mg} / \mathrm{kg})$. Immunotherapy was started while the marrow was still hypoplastic following induction chemotherapy, ie, just before full haematological remission was achieved. The immunotherapy consisted of weekly percutaneous injections of BCG (Glaxo Laboratories) using a multipuncture Heaf gun and subcutaneous or intradermal injections of irradiated allogeneic myeloblastic leukaemia cells (Powles et al., 1973). No chemotherapy was received by patients in remission during the period of investigation.
COLONY ASSAY

Bone marrow aspirates were taken from the iliac crest at various times after the induction of remission. One to five millilitres of bone marrow was taken into a syringe which had previously been rinsed with preservative-free heparin, and the incidence of colony-forming cells in the sample was measured using the agar diffusion chamber technique (Gordon et al., 1975). Although the results are expressed as the yield of colonies per $2 \times 10^{5}$ cells throughout, the low yields from the remission marrows necessitated an increase in the number of cells introduced into the chamber. This increase depended on the cellularity of the sample, but, where possible, up to $5 \times 10^{5}$ cells were cultured in each chamber.

The surviving fraction of colony-forming cells after exposure to cytosine arabinoside provides an indication of their proliferation rate relative to that of normal cells (Gordon and Douglas, 1975). These measurements were made by implanting chambers containing as many cells as possible into untreated mice and injecting the animal intravenously with cytosine arabinoside. The doses used were between 100 and $300 \mathrm{mg} \mathrm{kg}^{-1}$ which are on the plateau of the dose response curve. When the cells available were sufficient for only one point a dose of $200 \mathrm{mg} \mathrm{kg}^{-1}$ was used. Two hours later the chambers were removed from the primary group of mice and implanted into further irradiated (900 rad) animals for an incubation period of nine days.

\section{Results}

Figure 1 compares the incidence of colony-forming cells in the marrow of the 17 patients with acute myeloid leukaemia in remission, who were receiving weekly immunotherapy, with that of 40 control patients with haematologically normal marrow.

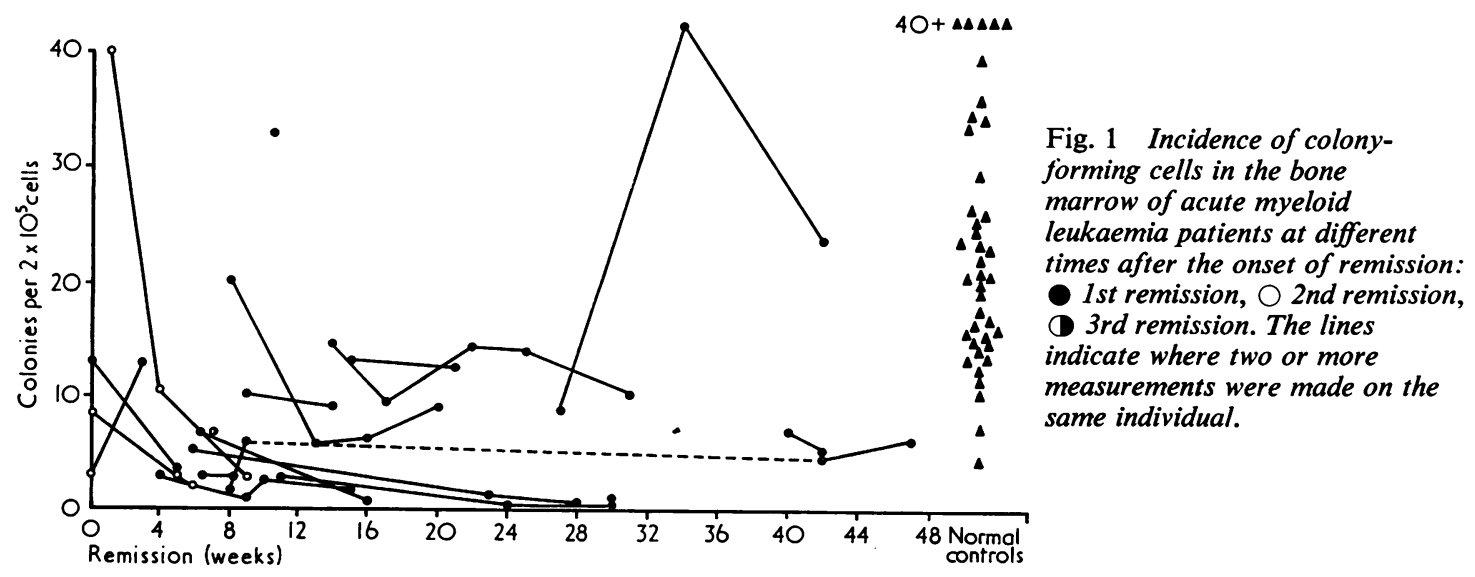


Table Clinical details and colony number of the acute myloid leukaemia patients studied

\begin{tabular}{|c|c|c|c|c|c|c|c|c|c|}
\hline $\operatorname{Age}(y r)$ & Sex & $\begin{array}{l}\text { Date } \\
\text { remission } \\
(1 \text { st } / 2 n d / 3 r d)\end{array}$ & $\begin{array}{l}\text { Date } \\
\text { relapse }\end{array}$ & $\begin{array}{l}\text { Remission } \\
\text { (months) }\end{array}$ & $\begin{array}{l}\text { Date } \\
\text { sample }\end{array}$ & & $\begin{array}{l}\text { Colonies } \\
\left(2 \times 10^{5}\right. \\
\text { cells })\end{array}$ & $\begin{array}{l}\text { Colonies/ml } \\
\text { aspirate }\end{array}$ & $\begin{array}{l}\text { Blood } \\
\text { granulocyte } \\
\left(\times 10^{-9} 1^{-}\right.\end{array}$ \\
\hline 47 & $\mathrm{~F}$ & 13 Aug 75 & 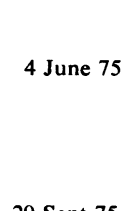 & $13 \cdot 5$ & $\begin{array}{r}23 \text { Apr } 75 \\
14 \text { May } 75 \\
4 \text { June } 75 \\
19 \text { June } 75 \\
29 \text { July } 75 \\
13 \text { Aug } 75 \\
17 \text { Sept } 75 \\
25 \text { Sept } 75\end{array}$ & $\mathrm{R} 2$ & $\begin{array}{c}3 \cdot 2 \\
12 \cdot 7 \\
0 \\
0 \\
0 \\
8 \cdot 5 \\
2 \cdot 8 \\
2 \cdot 3\end{array}$ & $\begin{array}{r}2,500 \\
4,600 \\
0 \\
0 \\
0 \\
22,100 \\
3,200 \\
1,750\end{array}$ & $\begin{array}{l}3 \cdot 2 \\
5 \cdot 9 \\
6 \cdot 2 \\
1 \cdot 3 \\
1 \cdot 5 \\
7 \cdot 4 \\
4 \cdot 3 \\
2 \cdot 3\end{array}$ \\
\hline 35 & $\mathbf{F}$ & $\begin{array}{r}26 \text { Aug } 71 \\
3 \text { Sept } 75\end{array}$ & $\begin{array}{l}29 \text { Sept } 75 \\
12 \text { Aug } 75\end{array}$ & $\begin{array}{l}1.25 \\
11.5\end{array}$ & $\begin{array}{l}10 \text { Sept } 75 \\
1 \text { Oct } 75 \\
5 \text { Nov } 75\end{array}$ & $\mathbf{R} 2$ & $\begin{array}{r}40 \cdot 5 \\
10 \cdot 6 \\
2 \cdot 6\end{array}$ & $\begin{array}{l}5,100 \\
4,600 \\
3,400\end{array}$ & $\begin{array}{l}5 \cdot 7 \\
5 \cdot 1 \\
4 \cdot 3\end{array}$ \\
\hline 52 & $\mathbf{F}$ & 10 Oct 75 & 19 Nov 75 & 1.25 & $\begin{array}{l}10 \text { Oct } 75 \\
13 \text { Nov } 75\end{array}$ & $\mathbf{R} 1$ & $\begin{array}{r}12 \cdot 8 \\
3 \cdot 0\end{array}$ & $\begin{array}{l}9,150 \\
4,500\end{array}$ & $\begin{array}{l}8 \cdot 5 \\
9 \cdot 9\end{array}$ \\
\hline 47 & $\mathbf{F}$ & 25 Mar 75 & 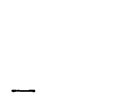 & $10+$ & $\begin{array}{l}15 \text { July } 75 \\
2 \text { Sept } 75 \\
7 \text { Oct } 75\end{array}$ & $\mathbf{R} \mathbf{I}$ & $\begin{array}{l}5 \cdot 4 \\
1 \cdot 7 \\
0 \cdot 5\end{array}$ & $\begin{array}{l}5,400 \\
6,400 \\
4,700\end{array}$ & $\begin{array}{l}6 \cdot 8 \\
6 \cdot 7 \\
6 \cdot 2\end{array}$ \\
\hline 66 & $\mathbf{F}$ & 4 Aug 75 & $4 \mathrm{Dec} 75$ & $4 \cdot 0$ & $\begin{array}{c}29 \text { Aug } 75 \\
24 \text { Sept } 75 \\
1 \text { Oct } 75 \\
5 \text { Nov } 75\end{array}$ & R1 & $\begin{array}{l}2 \cdot 7 \\
1 \cdot 0 \\
2 \cdot 6 \\
1 \cdot 8\end{array}$ & $\begin{array}{l}7,400 \\
4,000 \\
5,150 \\
3,350\end{array}$ & $\begin{array}{l}6 \cdot 6 \\
4 \cdot 1 \\
6 \cdot 3 \\
3 \cdot 8\end{array}$ \\
\hline 68 & $\mathbf{F}$ & 17 Feb 75 & ( & $12+$ & $\begin{array}{l}21 \text { May } 75 \\
18 \text { June } 75 \\
16 \text { July } 75 \\
13 \text { Aug } 75 \\
24 \text { Sept } 75\end{array}$ & $\mathbf{R} 1$ & \begin{tabular}{r|r}
$14 \cdot 8$ \\
$9 \cdot 3$ \\
$14 \cdot 4$ \\
$13 \cdot 9$ \\
$10 \cdot 4$
\end{tabular} & $\begin{array}{r}22,600 \\
16,550 \\
9,050 \\
34,600 \\
12,400\end{array}$ & $\begin{array}{l}6 \cdot 3 \\
5 \cdot 5 \\
6 \cdot 2 \\
7 \cdot 2 \\
5 \cdot 6\end{array}$ \\
\hline 67 & $\mathbf{F}$ & 30 May 75 & 4 Aug 75 & $3 \cdot 25$ & $\begin{array}{r}15 \text { July } 75 \\
1 \text { Aug } 75\end{array}$ & $\mathbf{R} 1$ & $\begin{array}{l}2.9 \\
2.9\end{array}$ & $\begin{array}{l}4,400 \\
8,950\end{array}$ & $\begin{array}{l}4 \cdot 7 \\
4 \cdot 0\end{array}$ \\
\hline 51 & $\mathbf{M}$ & 18 Mar 75 & 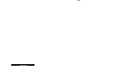 & $10+$ & $\begin{array}{r}2 \text { July } 75 \\
13 \text { Aug } 75\end{array}$ & $\mathbf{R} 1$ & $\begin{array}{l}13 \\
12 \cdot 7\end{array}$ & $\begin{array}{l}9,700 \\
7,550\end{array}$ & $\begin{array}{l}5 \cdot 2 \\
0 \cdot 7\end{array}$ \\
\hline 60 & $\mathbf{M}$ & 23 Sept 74 & 13 Aug 75 & 10.75 & $\begin{array}{l}24 \text { July } 75 \\
12 \text { Aug } 75\end{array}$ & $\mathbf{R} 1$ & $\begin{array}{l}7 \\
5 \cdot 5\end{array}$ & $\begin{array}{l}13,000 \\
12,000\end{array}$ & $\begin{array}{l}9 \cdot 7 \\
7 \cdot 7\end{array}$ \\
\hline 35 & $\mathbf{M}$ & 25 June 75 & - & $7+$ & $\begin{array}{l}21 \text { Aug } 75 \\
25 \text { Sept } 75 \\
16 \text { Oct } 75 \\
14 \text { Nov } 75\end{array}$ & R1 & $\begin{array}{r}20 \cdot 4 \\
5 \cdot 7 \\
6 \cdot 6 \\
9 \cdot 2\end{array}$ & $\begin{array}{r}15,400 \\
1,650 \\
4,400 \\
16,600\end{array}$ & $\begin{array}{l}5 \cdot 9 \\
5 \cdot 3 \\
\text { N.A. } \\
4 \cdot 9\end{array}$ \\
\hline 31 & $\mathbf{M}$ & 21 Jan 75 & - & $12+$ & $\begin{array}{l}22 \text { July } 75 \\
16 \text { Sept } 75 \\
11 \text { Nov } 75\end{array}$ & $\mathbf{R} 1$ & $\begin{array}{r}8 \cdot 6 \\
42 \cdot 5 \\
23 \cdot 8\end{array}$ & $\begin{array}{r}6,950 \\
16,000 \\
10,500\end{array}$ & $\begin{array}{l}7 \cdot 8 \\
6 \cdot 1 \\
7 \cdot 2\end{array}$ \\
\hline 43 & $\mathbf{F}$ & 31 July 75 & - & $6+$ & $\begin{array}{l}2 \text { Oct } 75 \\
6 \text { Nov } 75\end{array}$ & $\mathbf{R} 1$ & $\begin{array}{r}10 \cdot 6 \\
8.9\end{array}$ & $\begin{array}{l}3,200 \\
9,600\end{array}$ & $\begin{array}{l}4 \cdot 6 \\
4 \cdot 6\end{array}$ \\
\hline 17 & $\mathbf{F}$ & $\begin{array}{l}26 \text { Sept } 73 \\
13 \text { Feb } 74 \\
18 \text { Apr } 75\end{array}$ & $\begin{array}{l}31 \text { Dec } 74 \\
13 \text { Mar } 75 \\
\\
21 \text { Nov } 75\end{array}$ & $\begin{array}{r}15.0 \\
13.0 \\
\\
7.0\end{array}$ & 10 Oct 75 & $\mathbf{R 3}$ & 6.9 & 3,200 & $2 \cdot 8$ \\
\hline 51 & $\mathbf{F}$ & 16 Apr 75 & 14 Nov 75 & $7 \cdot 0$ & $\begin{array}{l}4 \text { July } 75 \\
3 \text { Oct } 75\end{array}$ & $\mathbf{R} \mathbf{I}$ & $\begin{array}{l}2 \cdot 7 \\
0 \cdot 3\end{array}$ & $\begin{array}{l}4,250 \\
3,700\end{array}$ & $\begin{array}{l}4 \cdot 7 \\
5 \cdot 2\end{array}$ \\
\hline 70 & $\mathbf{M}$ & $\begin{array}{l}23 \text { Aug } 74 \\
10 \text { June } 75\end{array}$ & 28 Apr 75 & 8.0 & $\begin{array}{l}25 \text { July } 75 \\
26 \text { Sept } 75\end{array}$ & $\mathbf{R} 2$ & $\begin{array}{l}6 \cdot 7 \\
0 \cdot 6\end{array}$ & $\begin{array}{r}10,200 \\
7,700\end{array}$ & $\begin{array}{l}\text { N.A. } \\
5.4\end{array}$ \\
\hline 66 & F & 31 Dec 74 & - & $13 \cdot 0$ & 28 July 75 & $\mathbf{R} 1$ & $0 \cdot 4$ & 6,800 & $6 \cdot 3$ \\
\hline 32 & $\mathbf{M}$ & 14 Nov 74 & 16 Oct 75 & 110 & $\begin{array}{c}9 \text { Jan } 75 \\
17 \text { July } 75 \\
4 \text { Sept } 75 \\
9 \text { Oct } 75\end{array}$ & R1 & $\begin{array}{l}1 \cdot 3 \\
5 \cdot 8 \\
4 \cdot 9 \\
6 \cdot 8\end{array}$ & $\begin{array}{l}5,200 \\
3,850 \\
2,400 \\
3,750\end{array}$ & $\begin{array}{l}1 \cdot 7 \\
7 \cdot 3 \\
7 \cdot 9 \\
4 \cdot 9\end{array}$ \\
\hline
\end{tabular}

R1 1st remission; $\quad$ R2 2nd remission;

R3 3rd remission;

RL relapse;

N.A. not available. 
With three exceptions, the incidence of colonyforming cells in the acute myeloid leukaemia patients remained well below the mean value for the control group ( 24.5 colonies per $2 \times 10^{5}$ cells) and there was little variation over the range of remission lengths studied. Some patients were studied over a period of several months when it was possible to obtain several consecutive samples. In all but one of these patients, the colony yields remained stable or tended to decrease as the length of remission increased.

The blood counts of these patients, while in remission, were usually found to be within the range for normal individuals (Table) although the bone marrow tended to remain hypocellular. The number of colony-forming cells in the marrow is a function of its cellularity and the incidence of colony precursors. The results may, therefore, be more meaningful when expressed as the number of colonies per millilitre of marrow, with the caveat that the aspirate is inevitably contaminated by peripheral blood. The results expressed in this manner are shown in Figure 2. In at least three cases there was evidence of marked oscillations in the numbers of colonies per millilitre, while in others all samples contained very low numbers of colony-forming cells. Only two measurements approached the mean value (2873 colonies $\mathrm{ml}^{-1}$ ) for the control group. There was no apparent difference between the remission lengths of patients in the oscillating and non-oscillating groups, and changes in the numbers of colony-forming cells per millilitre of marrow were not accompanied by similar changes in the blood granulocyte count (Table).

Figure 3 relates the sensitivity of the colony-

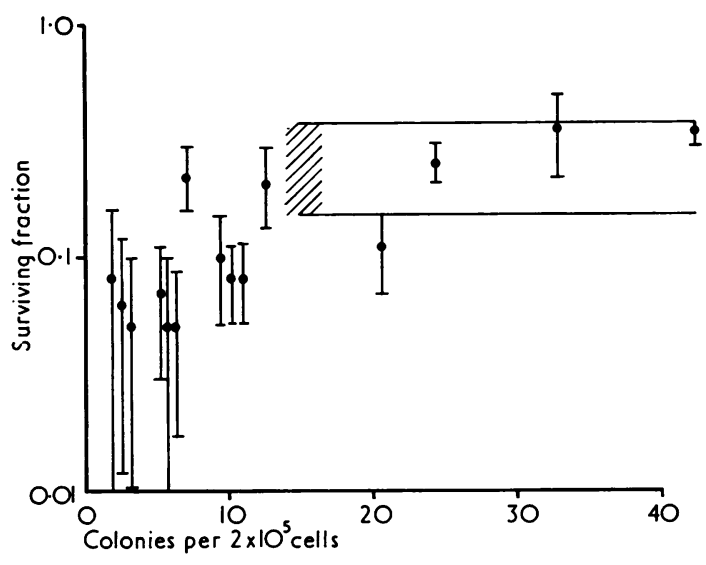

Fig. 3 Sensitivity of the colony-forming cells in remission marrows to cytosine arabinoside (100-300

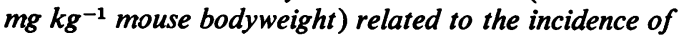
these cells. The sensitivity to the drug is expressed as the surviving fraction of the untreated control. The shaded area represents the range of sensitivity of normal colony-forming cells.

forming cells to cytosine arabinoside to their incidence in the marrow aspirate. These determinations depended on the numbers of cells available and could not be carried out for all patients at all time points. The points represent the mean survival of the colony-forming cells relative to the untreated control cultures in doses sufficient to reach the plateau on the dose-response curve $\left(100-200 \mathrm{mg} \mathrm{kg}^{-1}\right.$ mouse body weight-see Methods); the shaded area shows the range of survival for normal bone marrow colony

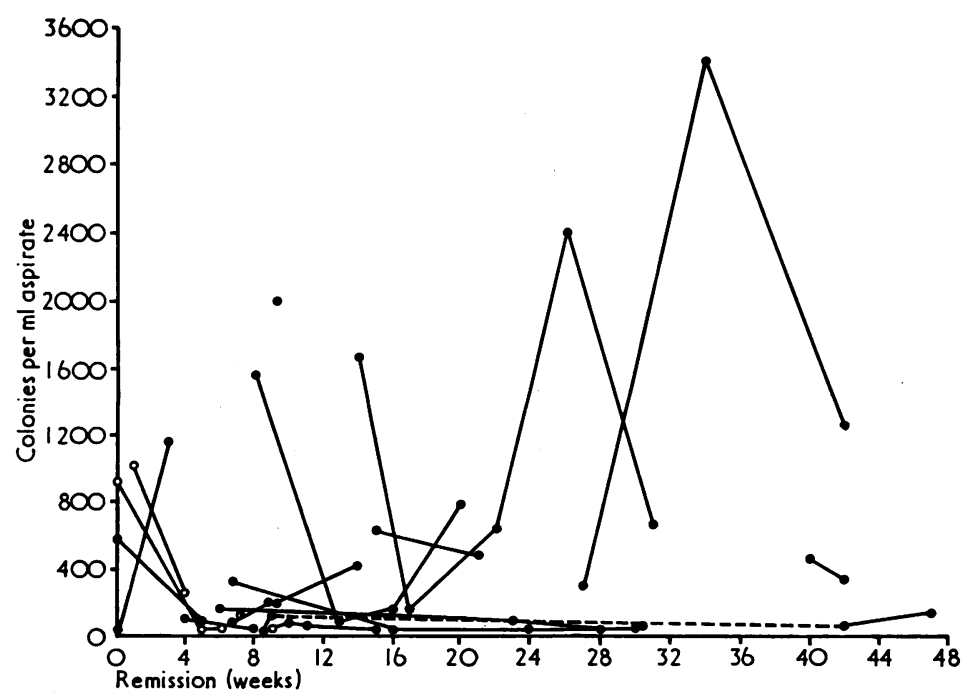

Fig. 2 The number of colonyforming cells per millilitre of aspirate from acute myeloid leukaemia patients at different times after the onset of remission: - 1st remission, $\bigcirc 2$ 2nd remission, - 3rd remission. The lines indicate where two or more measurements were made on the same individual. 
growth using the same doses of cytosine arabinoside. Although the material available and the resultant numbers of colonies limit confidence in the data, there is a definite trend towards increased sensitivity to cytosine arabinoside when the incidence of colony-forming cells is lower than 10 colonies per $2 \times 10^{5}$ cells while the sensitivity is within the normal range when the colony incidence is higher.

\section{Discussion}

The agar diffusion chamber technique provides favourable conditions for the growth of colonies from human bone marrow (Gordon et al., 1975). The colonies cultured from haematologically normal bone marrow aspirates contain granulocytic and mononuclear cells, and their incidence suggests that they derive from an early granulocytic precursor cell. These features, together with the similar morphology and development of colonies in diffusion chambers and in agar in vitro, indicate a close relationship between the cells cultured in these two systems. Additional data pertaining to the equivalence of diffusion chamber colonies and the in vitro CFU-C are available from studies using mouse bone marrow cells. Treatment with ${ }^{3} \mathrm{HTdr}$ inhibits the growth of murine colonies in diffusion chambers and in vitro to the same degree (Gordon, 1974), and the cells in the chambers are known to be exposed to the colonystimulating activity necessary for in vitro colony growth (Gordon and Blackett, 1975; Gordon and Lindop, 1975).

The present results show that patients with acute myeloid leukaemia may be maintained in remission with an adequate supply of blood cells despite subnormal numbers of granulopoietic colony-forming cells in the marrow. The effect of immunotherapy on this cell population is difficult to evaluate since there is no adequate control (non-immunotherapy) group of patients available for study. However, comparison of colony yields in early and late remission (Fig. 1) shows that immunotherapy does not act by increasing the incidence of these cells while Fig. 2 shows only transient increases in the total numbers of colonyforming cells in a few patients. The observed fluctuations in the numbers of colonies per millilitre were not accompanied by changes in the blood granulocyte count; neither were the blood counts of those patients with consistently low numbers of colony precursor cells per millilitre of marrow markedly different from those who achieved periodic high colony yields.

Immunotherapy does not appear to act by increasing the marrow reserve of these early granulocytic cells since there is no obvious or consistent increase in colony number with prolonged treat- ment, and the return to normal numbers of colonyforming cells reported by others during remission (Brown and Carbone, 1971; Moore et al., 1973; Bull et al., 1973) was not achieved. The maintenane of adequate blood granulocyte counts may, howeven, be related to the proliferative activity of the colong forming cells, resulting in an increased output of mature cells per colony precursor cell rather than increased renewal of the progenitor cell populatio $\overrightarrow{\text { P }}$ This idea was tested by measuring the sensitivity of the cells to cytosine arabinoside since an increas in the proliferation rate of colony precursor celis results in an increase in their sensitivity to thes drug (Gordon and Douglas, 1975). These exper? ments showed that a low incidence of colony cells in the marrow was related to an increase in their pr® liferation rate, and the results are therefore coosistent with the idea that the efficiency of granulocyte production is increased in these remission marrows at the expense of increasing the size of the precursor cell population.

Neither the results from the experiments using cytosine arabinoside nor the measurements of colony numbers support the idea that the success in reinducing remission and prolonging survival duringag second remission is due to a protective effect of prior immunotherapy on the marrow precursor ce $\overline{\mathrm{W}}$ since their proliferative state might be expected render them more, rather than less, vulnerable to tige cytotoxic effects of reinduction chemotherap $\vec{\nexists}$. Another mechanism for the beneficial effects of immunotherapy must therefore be sought.

The work was supported by grants from the Nation Cancer Institute (MYG) and the Leukaemia REsearch Fund (RLP).

We wish to thank Dr J. Russell for providing many of the samples used in this study, Mrs B. M. Pickering for expert technical assistance, and Professor L. F. Lamerton and Dr N. M. Blackept for their encouragement and guidance.

\section{References}

Brown, C. H. III and Carbone, P. P. (1971). In vitro growith of normal and leukemic human bone marrow. Journal 셩 the National Cancer Institute, 46, 989-1000.

Bull, J. M., Duttera, M. J., Stashick, E. D., Northup, Henderson, E., and Carbone, P. P. (1973). Serial in vifo marrow culture in acute myelocytic leukemia. Blood, 679-699.

Currie, G. A. (1972). Eighty years of immunotherapy: review of immunological methods used for the treatment ff $^{\prime}$ human cancer. British Journal of Cancer, 26, 141-153. $\frac{\vec{\Phi}}{\Phi}$

Gordon, M. Y. (1974). Quantitation of haemopoietic cedis from normal and leukaemic RFM mice using an in v/ colony assay. British Journal of Cancer, 30, 421-428.

Gordon, M. Y. and Blackett, N. M. (1975). Stimulation of granulocytic colony formation in agar diffusion chambers 
implanted in cyclophosphamide pretreated mice. British Journal of Cancer, 32, 51-59.

Gordon, M. Y., Blackett, N. M., and Douglas, I. D. C. (1975). Colony formation by human haemopoietic precursor cells cultured in semi-solid agar in diffusion chambers. British Journal of Haematology, 31, 103-110.

Gordon, M. Y. and Douglas, I. D. C. (1975). Changes in proliferation rate of human bone marrow colony-forming cells measured by a cytosine arabinoside-diffusion chamber method. European Journal of Cancer, 12, 551-555.

Gordon, M. Y. and Lindop, P. J. (1975). Studies on the humoral regulation of granulopoiesis in leukaemic RFM mice. British Journal of Cancer, 32, 186-192.

Klouda, P. T., Lawler, S. D., Powles, R. L., Oliver, R. T. D., and Grant, C. K. (1975). HL-A antibody response in patients with acute myelogenous leukaemia treated by immunotherapy. Transplantation, 19, 245-249.

Moore, M. A. S., Spitzer, G., Williams, N., Metcalf, D., and Buckley, J. (1974). Agar culture studies in 127 cases of untreated acute leukemia: the prognostic value of reclassification of leukemia according to in vitro growth characteristics. Blood, 44, 1-18.

Moore, M. A. S., Williams, N., and Metcalf, D. (1973).
In vitro colony formation by normal and leukemic human hemopoietic cells: characterization of the colony-forming cells. Journal of the National Cancer Institute, 50, 603-623.

Powles, R. L. (1973). Immunotherapy for acute myelogenous leukaemia. British Journal of Cancer, 28, Supplement 1, 262-265.

Powles, R. L. (1976). Immunotherapy in the management of acute leukaemia. British Journal of Haematology, 32, 145149.

Powles, R. L., Balchin, L. A., Hamilton Fairley, G., and Alexander, P. (1971). Recognition of leukaemia cells as foreign before and after autoimmunization. British Medical Journal, 1, 486-489.

Powles, R. L., Crowther, D., Bateman, C. J. T., Beard, M. E. J., McElwain, T. J., Russell, J., Lister, T. A., Whitehouse, J. M. A., Wrigley, P. F. M., Pike, M., Alexander, P., and Hamilton Fairley, G. (1973). Immunotherapy for acute myelogenous leukaemia. British Journal of Cancer, 28, 365-376.

Robinson, W. A. and Pike, B. L. (1970). Colony growth of human bone marrow cells in vitro. In Symposium on Hemopoietic Cellular Proliferation, edited by F. Stohlman, Jr., p. 249-259. Grune and Stratton, New York. 